\title{
Enhancing Cloud based E- Learning using Knowledge Sharing System
}

\author{
ARUNA.R \\ M.Phil (CS) Research Scholar \\ SCSVMV University \\ Enathur, Kanchipuram
}

\author{
S.PRAKASAM, Ph.D \\ Assistant Professor \\ Department of CSA, SCSVMV University \\ Enathur, Kanchipuram
}

\begin{abstract}
The developing countries will be know the technology and innovation to everywhere throughout the country including small rural areas. In which information communication technology (ICT) is being used to transform education. In this research in detail the various level of education base elearning in cloud computing are servile. The challenge faced by cloud users and providers are security concerns towards cloud services. These security issues acts as a barrier in the growth of cloud computing. The trust between provider and users is the most important factor to be considered for a cloud service and application. Here we present an analysis of survey issues in a cloud environment. Solution exists to a certain extent for various issues. There are trust based solutions available to provide security in various collaborative environments. These papers describe enhancing cloud based e-learning system in detail.
\end{abstract}

\section{INTRODUCTION}

Cloud computing provides a variety of computing resources from server and storage to enterprise applications such as email, security, backup, voice all delivered over the internet. It provides delivers a hosting environment that is immediate flexible, scalable, secure. It is one of the new technology trends likely to have a significant impact on the teaching and learning environment.

There are several cloud computing services provides that offer support for educational systems among there are Amazon, Google, yahoo, Microsoft E-Learning is widely used today on different educational levels continuous education computing trainings, academic courses there are at least two entities in valued in an e-learning system the students and the trainers

\section{EXISTING CLOUD BASED E- LEARNING}

\section{Traditional e-learning network to cloud e-learning}

E-Learning is an internet - based learning process, using Internet technology to design, implement, select, manage, support and extend learning, which will not replace traditional education methods, but will greatly improve the efficiency of education. As e-learning has a lot of advantages like flexibility, diversity, measurement, opening and so on, it will become a primary way for learning in the new century as in Mendez [19] illustrate that in traditional web - based learning mode, system construction and maintenance are located inside the educational institutions or enterprises, which led to a lot of problems, such as significant investment needed but without Capital gains for them, which leads to a lack of development potential. In contrast, cloud - based e-learning model introduces

Scale efficiency mechanism, i.e. construction of e-learning system is entrusted to cloud computing suppliers, which can make providers and user to achieve a win-win situation. The cloud based environment supports the creation of new generation of e-Learning systems, able to run on a wide Range of hardware devices, while storing data inside the cloud.

Ouf [20] has presented an innovative e-learning ecosystem based on cloud computing web 2-0 technologies. The article analyses the most important cloud - based services provided by public cloud computing environments such as Google App Engine, Amazon Elastic Compute Cloud (EC2) or Windows Azure, and highlights the advantages of deploying E-Learning 2.0 applications for such an infrastructure. The authors also identified the benefits of cloud based E-Learning 2.0 applications (scalability, feasibility, or availability) and underlined the enhancements regarding the cost and risk management.

Chandral[21] focused on current e-learning architecture model and on issues in current e-learning applications. The article presents by hybrid instructional Model as the blend of the traditional classroom and online education and its customization for e-learning applications running on the cloud computing infrastructure. The authors underline the e-learning issues, especially the openness, scalability, and development / customization costs. The existing

E-learning systems are not dynamically scalable and hard to extend integration with other e-learning system is very expensive. The article proposed the hybrid cloud delivery model that can help in fixing the mentioned problems.

In this article a new paradigm is highlighted in educational area by introducing the cloud computing in order to increase the scalability, flexibility and availability of e-learning system. The authors have evaluated the traditional e-learning networking model, with its advances and issues, and the possibility to move the e-learning system out of schools or enterprises, inside a cloud computing infrastructure. The separation of entity roles and cost effectiveness can be considered important advantage. The institution will be responsible for the education process, content management and delivery and the vendor takes care of system construction, maintenance, development and management. The

e-learning system can be scaled, both horizontally and vertically, and the educational organization is charged according to the number of used servers that depends on the number of student as in

According to manop phankokkruad. 2012 [1] has addressed the problems of the cloud computing as, the classical elearning system is based on client / server architecture thus they lack of the scalability, flexibility and interoperability. It makes the learning resources cannot share, and the system improvement is not easily. In their paper [1]. Authors have proposed a new architecture for 
E-learning system that the architecture separate into three layers includes infrastructure, platform and application.

On infrastructure layer, the learning resource from the traditional system are transferred to the cloud database instead of the usual DBMS whereas on platform layer, a new elearning system that consists of the CMS, AMS, and other service components were developed to be the intermediary between cloud database and the applications. Finally on application layer, CAT web application and WBI application were developed for interacting with the student's client [1].

Data portability is very important in educational sectors. Student does several projects and research works on diverse fields. Moreover they collect several materials associated with their study like lecture, slides and various supplementary documents. However, today security is a very big concern for everybody residing in a country. Hard drive failure is an ineluctable phenomenon in the contemporary Endeavour. Most of the time the task done by the students destroys due to the computer virus attack. Hardware failure or inefficient management of PC.

Due to the poor economical condition the government can serve only few computers to each institute which is approximately 0.782 per 100 people [14] moreover the survey performed by the organization amader gram [15] shows that the government can provide computer only $35 \%$ school out of its total school.

However the fulfillment of software requirement is even more severe than hardware fulfillment. Since the government cannot afford the high price software for each institute therefore the use of pirated software is increasing day by day. It is often observed that the pirated software has lots of problems and does not give the exact performance what the legitimate one does. In addition the vendors are also depriving from getting there revenue due to the increasing use of pirated version of software. Since the current system does not have any concept of resource sharing so the government cannot fulfill individual demand by supply unique resource for each of them due to the low economic condition of the country. According to our survey we find that most of the institutes do not their PCs for the $40 \%$ of the total working hour on an average. In our proposed architecture the cloud system has the knowledge of all unused resources and assigns resources from those free portions if any request arrives. In our designed architecture the partners associated with the cloud system offers software to the cloud for individual user with a reasonable price rate.

Distance learning education provides opportunity to carry on a course of study while balancing other commitments. In our education system it is observed that there is a massive difference between the knowledge provides in urban area to that of rural one. In urban areas we find some serious flaws in number of teachers, the quality of teachers or the availability of various updated resources such as different e-learning toolkits. Moreover some people stay and work in a distant area has little access to higher education or their responsibility to job prevent them from catching the scheduled lectures. Sometimes the course that someone intended to complete is available at a provider that is an inconvenient distance from where he lives. Thus the student completing their education in rural area fined themselves way behind in knowledge when they are facing interview for a job or thinking for higher studies. In our proposed architecture we are bindings all the areas ranging from urban to rural one into a single domain of cloud system and are facilitating every institute to collect the different material related to their education by offering the elearning services. Since the government now offers those services with a very minimum charge so everybody including teacher to student will now improve their knowledge with those updated resources. This will definitely lesson the knowledge barrier between the students all over the country.

Mikroyannidis states that the cloud offers a lot of services for building adaptive and customizable cloud Learning Environments (CLE). He also explains how CLEs extend the borders of the learning environments beyond of educational organization. Additionally this work proposes a learning scenario based on the use of cloud learning services. Thus, to advantage of these features educational institutions are also moving towards providing their services by using cloud technologies. However, in the educational domain, services are scarcely adapted and offered in cloud.

Table 1.1 Comparative study of existing Cloud based e-learning methods

\begin{tabular}{|c|c|c|}
\hline $\begin{array}{c}\text { Exiting System } \\
\text { Name/ Author } \\
\text { Name/ Year } \\
\end{array}$ & $\begin{array}{l}\text { Advantage of } \\
\text { Methodology }\end{array}$ & Limitation \\
\hline $\begin{array}{l}\text { Computing/Md.Anwar } \\
\text { Hossain Masud, } \\
\text { Xiaodi } \\
\text { Huang/2012 }\end{array}$ & $\begin{array}{l}\text { It provide } \\
\text { public cloud } \\
\text { computing } \\
\text { environments } \\
\text { such as EC2 } \\
\text { Google app } \\
\text { engine also } \\
\text { creation of new } \\
\text { generator of e- } \\
\text { learning } \\
\text { systems It like } \\
\text { flexibility, } \\
\text { diversity, } \\
\text { measurement, } \\
\text { opening }\end{array}$ & $\begin{array}{l}\text { e-learning is } \\
\text { an internet } \\
\text { based } \\
\text { process } \\
\text { using } \\
\text { internet } \\
\text { technology } \\
\text { to } \\
\text { design } \\
\text { implement } \\
\text { select, } \\
\text { manage and } \\
\text { extend } \\
\text { learning, } \\
\text { which will } \\
\text { not replace } \\
\text { traditional } \\
\text { education } \\
\text { methods }\end{array}$ \\
\hline $\begin{array}{l}\text { Enhanced virtual e- } \\
\text { learning environments } \\
\text { using cloud } \\
\text { computing } \\
\text { Architectures/Eugen } \\
\text { Zaharescu/2012 }\end{array}$ & $\begin{array}{l}\text { The EC } 2 \text { users } \\
\text { rent out from } \\
\text { Amazon virtual } \\
\text { machines that } \\
\text { can be accessed } \\
\text { remotely. It is } \\
\text { computing } \\
\text { power storage } \\
\text { capabilities } \\
\text { software } \\
\text { platforms and } \\
\text { services device } \\
\text { and location } \\
\text { independence } \\
\text { enables }\end{array}$ & $\begin{array}{l}\text { data security } \\
\text { require a } \\
\text { high level } \\
\text { Qos quality } \\
\text { of services } \\
\text { management } \\
\text { and need for } \\
\text { backup is } \\
\text { critical }\end{array}$ \\
\hline $\begin{array}{l}\text { Cloud based } \\
\text { architecture for an } \\
\text { affective } \\
\text { recommender system }\end{array}$ & $\begin{array}{l}\text { The cloud } \\
\text { offers a lot of } \\
\text { service for } \\
\text { building }\end{array}$ & $\begin{array}{l}\text { The service } \\
\text { layer } \\
\text { includes two } \\
\text { storage }\end{array}$ \\
\hline
\end{tabular}




\begin{tabular}{|c|c|c|}
\hline $\begin{array}{l}\text { of learning } \\
\text { resources/Derick } \\
\text { leony, Abelardo } \\
\text { pardo, Hugo A. } \\
\text { Parada g., }\end{array}$ & $\begin{array}{l}\text { adaptive and } \\
\text { customizable } \\
\text { cloud learning } \\
\text { environments } \\
\text { advantage of } \\
\text { features } \\
\text { educational } \\
\text { institutions are } \\
\text { also moving } \\
\text { towards } \\
\text { providing their } \\
\text { services by } \\
\text { using cloud } \\
\text { technologies in } \\
\text { the educational } \\
\text { domain, } \\
\text { services are } \\
\text { scarcely } \\
\text { adapted offered } \\
\text { in cloud }\end{array}$ & $\begin{array}{l}\text { elements to } \\
\text { keep the } \\
\text { information } \\
\text { of the } \\
\text { learning } \\
\text { resources } \\
\text { and the } \\
\text { learners } \\
\text { affective } \\
\text { states the } \\
\text { storage for } \\
\text { learners } \\
\text { affective } \\
\text { state is } \\
\text { updated by } \\
\text { requests } \\
\text { from the } \\
\text { client layer }\end{array}$ \\
\hline $\begin{array}{l}\text { E-learning improved } \\
\text { architecture for } \\
\text { clouds/Gunjita } \\
\text { shrivastava, Anukrati } \\
\text { dubey \&sandeep } \\
\text { sahu/2013 }\end{array}$ & $\begin{array}{l}\text { Cloud } \\
\text { computing is a } \\
\text { wide area } \\
\text { network based } \\
\text { computing the } \\
\text { shared } \\
\text { resources such } \\
\text { as software and } \\
\text { information are } \\
\text { provided to } \\
\text { computer and } \\
\text { other devices it } \\
\text { is computing } \\
\text { facilitates the } \\
\text { equal flow of } \\
\text { data between } \\
\text { the outsourced } \\
\text { and outsourcing } \\
\text { servicer the } \\
\text { easily flow of } \\
\text { information in } \\
\text { the host } \\
\text { organization }\end{array}$ & $\begin{array}{l}\text { It leads to } \\
\text { management } \\
\text { problems the } \\
\text { webmaster } \\
\text { will have to } \\
\text { set up new } \\
\text { systems for } \\
\text { dealing with } \\
\text { the conflict }\end{array}$ \\
\hline
\end{tabular}

\section{SECURITY IN E- LEARNING BASED SYSTEM}

In cloud computing paradigm, a cloud provider creates, deploys and manages the resources, application and services. Multi tenancy and virtualization are the key features to make efficient utilization of the existing resources and application. A single server, computing facility, data centre and operating system hosts many users, using virtualization. A large number of users are getting served by a cloud provider by this concept of resources sharing. Data protection, communication, resource management for isolation, virtualization etc. are some of the security issues arises due to multi-tenancy and virtualization in the cloud environment.

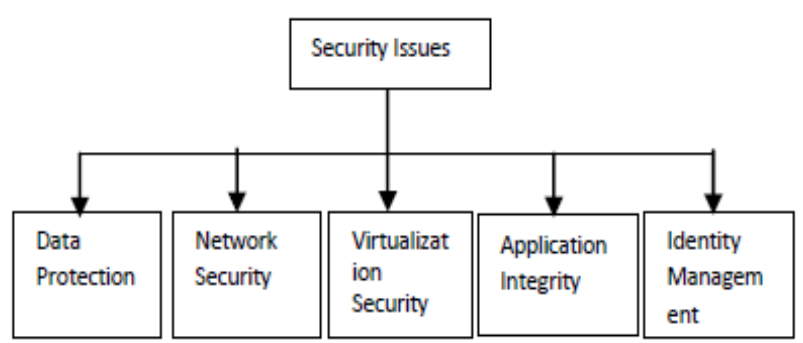

Fig: 1

\section{PROPOSED CLOUD BASED ARCHITECTURE USING KNOWLEDGED SHARING SYSTEM}

In this work, architecture of Cloud based E- learning using Knowledge sharing System is used. Knowledge sharing system includes such as resources from learning objects, open educational resources, mobile education, Curriculum development, etc. The e-learning cannot completely replace teachers; it is only updating for technology, concepts and tools, giving new content, concepts and methods for education, so the roles of teachers cannot be replaced. The teachers will still play leading roles and participate the developing and making use of e-learning cloud. The blended learning strategy should improve the educational act. On the other hand, E-learning cloud is a migration of cloud computing technology in the field of e-learning, which is a future e-learning infrastructure, including all the necessary hardware and software computing resources engaging in elearning. After these computing resources are virtualized, they can be afforded in the form of services for educational institutions, students and businesses to rent computing resources. E-learning cloud architecture.

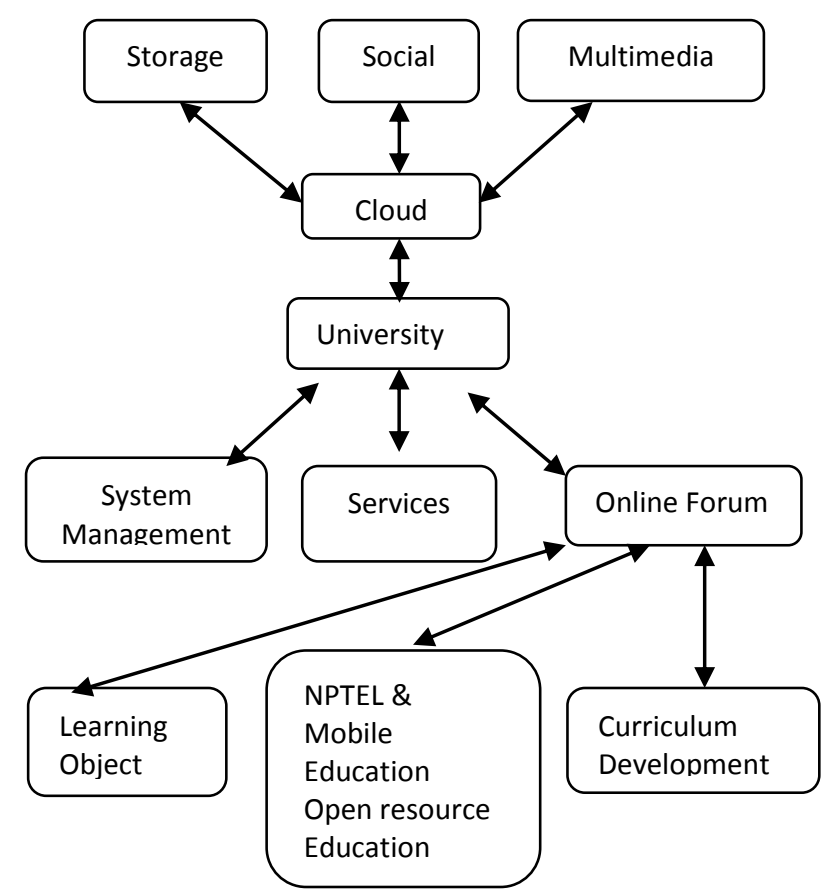

Figure: 1.1 


\section{FORUM}

Forum offer syllabus, hits to dispel doubts, solutions to academic hardships and answer to every important question in the lessons in this system. This facility enables students to educate themselves. Those who take membership in this can avail all facilities. Further, they can share their ideas and opinions on newly developed software. The level of security in this system is always high. While discussing the merits and demerits of newly developed software, students are benefited much and tend to use the technology more. Those who are not members of this system cannot avail this facility.

What are the technologies and facilities available and used by the faculty for effective teaching eg: Virtual laboratories, elearning - resources from National Program on Technology Enhanced Learning (NPTEL) and National Mission on Education through Information and Communication Technology (NME-ICT), open educational resources, mobile education, etc. the students and the faculty members share knowledge on a forum

\subsection{Advantage of New Proposed Method}

i) Powerful computing and storage capacity cloud based e-learning architecture locates the computing and data in a large number of distributed computers. It provides power of huge data storage space, puts the cloud as a service available to students via the internet

ii) High availability through the integration of mass storage and high performance computing power this system can provide a higher quality of service.

iii) Virtualization is the most important characteristics it is managed, expensed, migrated, and backup through virtualization platform. It put the underlying hardware, including servers, storage and networking equipment, comprehensive virtualization, in order to build a resources pool of shared, distributed on-demand

iv) The major advantage of the proposal is that it aims at providing easy access the software is also upgraded from time to time as per requirement. Moreover the college has enabled Wi-Fi facility to the classrooms for internet access and has also created an online lesson plan management system for the staff members to access the same even at their homes

v) In the e-learning model, teachers assign teaching tasks, conduct regular lectures, or train student's skills. The students attend the online autonomous learning act assignments and teachers also answer students' questions and offer essential teaching to major and difficult points

vi) Teachers can also use multimedia to enhance teaching content. Students work out their own learning plans, determining learning methods autonomously. They conduct on-line autonomous learning when they study each unit, finish its test via internet and do some statistics to the test results. Teachers also encourage students to cooperate with each other to finish simple learning tasks or complex group-based projects The people will be improved and abilities to express themselves will be enhanced

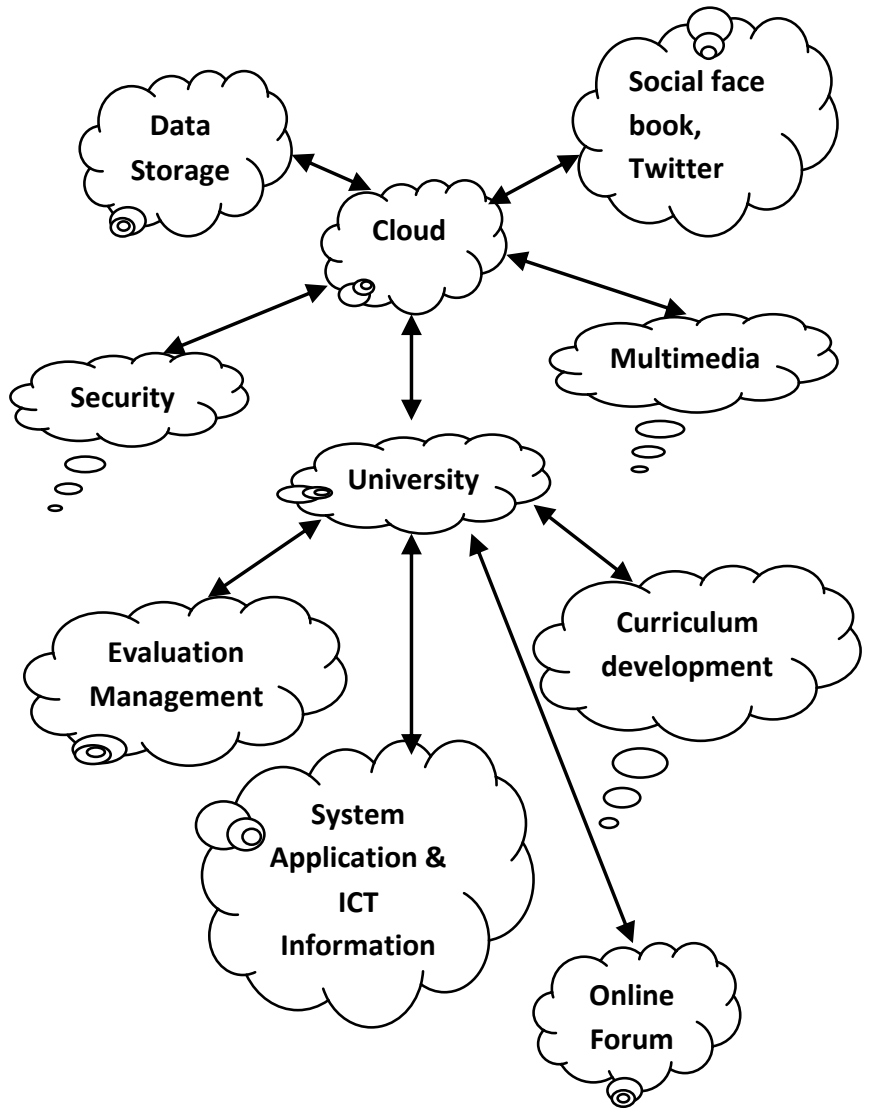

Figure: 1.2

\section{CONCLUSION}

Cloud computing has recently emerged as a compelling paradigm for managing and delivering services over the internet. It is rapidly changing landscape of information technology and ultimately turning to the long-held promise of utility computing into a reality. This practice is aimed to provide an online knowledge-sharing platform for faculty \& students. This online forum provides an opportunity for faculty and students to meet online and share knowledge. This practiced is expected to create knowledge explosion. The college administration also uses this forum as a tool to provide details information on policy rules \& regulations of the institution.

\section{REFERENCES}

[1] Pearson, S. "Taking account of privacy when designing cloud computing services" Software Engineering Challenges of Cloud Computing, 2009, pages, $44-52$, Vancouver, BC.

[2] Saurabh, "Security issues in cloud Computing", http://serl.iiit.ac.in/cs6600/saurabh.ppt, 2009.

[3] Tetsuya, M. Kazuhiro, S. Hirotsugu, K. "A system for search, access restrictions and agents in the Clouds", Ninth Annual International Symposium on Applications and the Internet Cloud, 2009. Pages 201-204, Japan.

[4] Carl Almond, "A Practical Guide to Cloud Computing Security",

http://www.avanade.com/Documents/Research\%20anad \%20Insights/practicalguidetocloudcomputingsecurity574 834.pdf, August 2009 
[5] Yin Zhixi, "A Secure Trust Model Based on Trusted Computing", International Conference on E-Business and Information System Security, 2009, pages $1-7$, Taiyuan.

[6] RG Cloud Group http://research.spec.org/workinggroups/rg-cloud-working-group.html

[7] M. Gaeta, F. Orciuoli, P. Ritrovato, Advanced ontology management system for personalised e-Learning, Knowledge-Based Systems, Vol-ume 22, Issue 4, May 2009, Pages 292-301, ISSN 0950-7051, 10.1016/j.knosys.2009.01.006.

[8] Hamsiah Mohd Dahalan, Raja Maznah Raja Hussain, Development of Web-Based Assessment in Teaching and Learning Management System (e-ATLMS), Procedia Social and Behavioral Sciences, Vol-ume 9, 2010, Pages 244-248, ISSN 1877-0428, 10.1016/j.sbspro.2010.12.144

[9] Salem Alkhalaf, Steve Drew, Thamer Alhussain, Assessing the Impact of e-Learning Systems on Learners: A Survey Study in the KSA, Pro-cedia - Social and Behavioral Sciences, Volume 47, 2012, Pages 98-104, ISSN 1877-0428, 10.1016/j.sbspro.2012.06.620.

[10] Mehmet Ali Salahli, Muzaffer Ozdemir, Cumali Yasar, Building a Fuzzy Knowledge Management System for Personalized E-learning, Procedia - Social and Behavioral Sciences, Volume 46, 2012, Pages 19781982, ISSN 1877-0428, 10.1016/j.sbspro.2012.05.414.
[11] E.Tuncay, "Effective use of Cloud computing in educational institutions," Procedia Social Behavioral Sciences, p. 938-942, 2010.

[12] S. Ouf, M. Nasr, and Y. Helmy, „An Enhanced ELearning Ecosystem Based on an Integration between Cloud Computing and Web2.0", Proc.IEEE International Symposium on Signal Processing and Information Technology (ISSPIT), pages 48-55, 2011.

[13] D. Chandran and S. Kempegowda, „Hybrid E-learning Platform based on Cloud Architecture Model: A Proposal", Proc. International Conference on Signal and Image Processing (ICSIP), pages 534-537, 2010.

[14] R. Hua, "Teaching Information System Based on Cloud Computing", Computer and Telecommunications, 2010.02, pp. 42-43.

[15] A. Hossain Masud, X. Huang, - An E-learning System Architecture based on Cloud Computingl, World Academy of Science, Engineering and Technology, Vol 62, 2012.

[16] Hossain Masud, X. Huang, - A Novel Approach for Adopting Cloud-based E-learning Systemll, 2012 IEEE/ACIS 11th International Conference on Computer and Information Science, China, pp 37-42.

[17] K. Verbert, N. Manouselis, X. Ochoa, M. Wolpers, H. Drachsler, I. Bosnic, and E. Duval, "Context-aware ecommender Systems for Learning: a Survey and Future Challenges," To appear in IEE Transactions on Learning echnologies, 